\title{
AN ANALYSIS OF INDONESIAN MORAL VALUES FOUND IN THE SONG LYRICS FORGIVE ME ALBUM BY MAHER ZAIN
}

\author{
Lutfy Fajar Hudayah \\ Ahmad Dahlan University, Indonesia \\ lutfyfajarhudayah@gmail.com
}

\begin{abstract}
Moral values are standard accepted principles of life. It is concerned with the principles of right and wrong behavior and the goodness or badness of human characters. Moral values from a subset of the set of all values, and value simply consist of the things that some people values. The purpose of this study were as follows (1) to find out the Indonesian moral value in song lyrics album by Maher Zain, (2) to find out the kinds of the moral values in the song lyrics album by Maher Zain and (3) to find out the most frequent moral values in the song lyrics album by Maher Zain. Subject in this study are song lyrics that consider and containing moral values. This study was qualitative descriptive because this study is aim to make systematic, factual, accurate description of the moral values in the song lyrics forgive me album. The data was analyzed systematically based on the data Moleong (2009: 6) who state that qualitative research is a kind of research carried out to understand the phenomena that occur in research subject such as musical note; intonation and meaning of song lyrics by describe it in words and using various scientific method. The result of this analysis is shown eleven moral values are found in Forgive Me album by Maher Zain songs. The similarities Indonesian moral values wih the moral values found $\mathrm{n}$ Maher Zain songs, and the moral values most frequent in forgive me album by Maher Zain song. The findings of the moral values in Forgive me album by Maher Zain are eleven. There are religiosity, love affection, loyalty, sincerity, thankfulness, steadfastness, humbleness, peace loving, brotherhood, respecting other, and optimism. The Indonesian moral values found in the song lyrics album are religiosity, communicative, and peaceloving. And the moral values most frequent in the song lyrics album are religiosity, love affection and loyalty.
\end{abstract}

Keywords: moral values, song lyric, Maher Zain

\section{INTRODUCTION}

Globalization brings both positive and negative effect. It gives great development in science, technology, economy, education and art. The development of art runs fast and music or song is one of the art branches that hasbig influence for students. Music is an entertainment that tells a story by mental image that giving the illusion and it is necessary because it becomes part of human life in this modern era. People do not getting out of music; they need music to entertain when they work, study, relax or lazing. Music may represent the bad or good of human feeling; it is able to express their thoughts, experiences, emotions, and faith. Besides that, music also invites the audiences to come into new world, new life when they are listening the lyrics of the songs by singer. The effects of the music are not only influencing the people emotion but also music is being able to change brain waves and make the brain more receptive to learn. In addition, music is a part of literary works.

Morality is a common word to say, but it is very difficult to imply in human daily life. Since people were born they had been taught about morality, however by the time the morality will decrease or delay. Morality is something that must be owned by human because without morality human will not be respected by other people. People will be easy to socialize with people around them and will be 
accepted in the community. Moral values can not only be obtained by discussion in formal situation and getting from books but also people can use songs to deliver the moral message of the songs.

Referring to the study of Paramitha (2015) under the title "An Analysis of Moral Values in Wreck It Ralph Movie directed By Rich Movie, containing what the question of moral values in the cartoon movie Wreck it Ralph movie it found that there were ten moral values in the movie. They are bravery, enthusiasm, kind hearted, honesty, love and affection, loyalty, peace loving, perseverance, sacrifice and self-confidence.

In addition, Susanti (2013) in her study, “An Analysis of Moral Values Taken from Edensor Novel By Andrea Hirata" found the moral values in the novel like never give up, nationalism, empathy to each other, strength of heart, optimism and positive thinking, believing God, Never stop learning, and struggle for life.

Currently, there are 18 Indonesian moral values formulated in Indonesian senior high school curriculum. Thus the researcher wants to examine the similar Indonesian moral values with those exist in the song Maher Zain.The 18 Indonesia moral values are religious, honest, tolerance, discipline, hard work, creative, independent, democratic, curiosity, the spirit of nationalism, patriotism, recognize excellence, friendship, love peace, love reading, care for the environment, social care, and responsibility (Pusat Kurikulum Diknas, 2010). Referring to the explanation above, it is very challenging or interesting to do a research on the moral values in Maher Zain songs because his Album got a Platinum appreciation from Warner Music Malaysia in 2012. Those songs can relax people's mind and they have a deep meaning for the listener. Therefore, many people like those songs. Furthermore, the song lyrics were written by the singer himself, therefore he sings the song with full of heart. So, the researcher interested in analyzing the song lyrics as stated in the title of the study "An Analysis of Moral Values in Song Lyrics of Forgive Me Album by Maher Zain".

\section{LITERATURE REVIEW}

2.1. Concept of Moral Values

Moral values are standard accepted principals of life. It is concerned with the principals of right and wrong behavior and the goodness or badness of human characters. Moral values from a subset of the set of all values, and a value simply consist of the things (abstract or concrete) that some people values. Likewise (2002) adds that moral is pertaining to character and behavior from the point of view of right and wrong. Walker (1998) flattens that moral is awareness and human ability to feel and learn particular things then for expressing judgment and feeling in the response appropriate to them. Rae (2000) says that moral primarily refers to the question of right or wrong and the capability to differentiate between two of them and the justification of them. To make them up, Young (1949) clarifies that moral concerning with consensus and culture, the correctness and proper art.

\subsection{Concept of Song Lyrics}

Song lyric is the verbal symbol that created by human. Human is the creature that knows how to react not only in the physical environment but also in the symbols that they made (Rivers, 2003).

\subsection{Concept of Song}

River (2003) a song is a relatively short musical composition. Songs contain vocal parts that are performed with the human voice and generally feature words (lyrics), commonly accompanied by other musical instruments (exceptions would 
be a cappella and scat songs). The words of songs are typically of a poetic, rhyming nature, although they may be religious verses or free prose. Songs are typically for a solo singer, though there many also be a duet, trio, or more voices (choral)

Another definition of song is suggested in Longman Modern Dictionary (2000: 1056) which states that song is the act of singing, short composition in which word and music combined together for unity. It means that song cannot be separate from the music. Song and music are related to each other in order to make good symphony. Song is a kind voice which has rhythm and music is the rhythm.

\subsection{Concept of Lyrics}

Lyric come from Ancient Greece has means a piece for single voice, to be accompanied by the lyre. The song lyric is specifically intended for singing. This intention affects diction, content and stanza form. The song lyric is particularly unified and simple. A tune has its own emotional character, and it is words will need to be of words and music (Little, 1970).

From the explanation above, it can be concluded that song lyric is symbolic reaction of human. It is a response of everything that is happened and felt by their physical environment and it is influenced by common sense and rationality. Symbol is used by human to understand a reality cannot be seen directly, but it can be seen and felt by human senses. This stimulus is processed and created by mind. Then, the concept or the specific interpretation will be formed a specific meaning appropriate with what will be pronounced.

2.5. Maher Zain

Maher Zain was born March 16, 1981 in Tripoli, Lebanon. He is a Moslem Swedish singer, songwriter, composer, musician and music producer of Lebanese origin. He comes from Sweden and his genres are R\&B, Soul Music, Pop Music, Acoustic music and Nasheed.

\section{METHODS}

The research design of this study was descriptive qualitative. This research belongs to qualitative research because this study is aimed to make systematic, factual, accurate description of the moral values in the song lyrics forgive me album. The source of the data in this study wassong lyrics forgive me album. Thus, the subjects were the part of song lyrics that consider and containing moral values. And later on, the subject will be compared in the 18 moral values in Indonesia. The song lyrics forgive me album are: I Love You so , Number One for Me, Mawlaya, My Little Girl, Forgive Me , One Big Family , AssalamuAlayka, Paradise , RaddhituBillahiRabba, Freedom, So Soon, Guide Me All the Way. The researcher used herself as an instrument to obtain the data because the study was descriptive study. Referring to the purposes of the study, the researcher will collect the data by using document (song lyrics).The instruments of document are song lyrics of forgive me album by Maher Zain, then 18 criteria of moral values in Indonesia and also moral values sheets made by the researcher. Then, the researcher found moral values in her research. In data collection technique, the researcher does finding out the relevant information from the case being studied by reading the song lyrics and finding information from the internet that deals with case, collecting the song lyrics forgive me album, than reading the song lyrics forgive me album, after that taking note on act and the utterances considered having moral value, and the last steps is identifying the moral values. In this research, the researcher does the step of Miles and Huberman (in Emzir, 2010) in analyzing the data. In data reduction, the researcher collecting the data by selecting and simplifying the data or information 
from the song lyrics "Forgive Me" album and also various sources that relevant to the study. In this process, researcher will reduce some data which don't have a close connection or not suitable to the research. It was meant that the data lack in representing moral values will be reduced. Then, when the data reduction has done, the result will be managed based on its categories of moral values found in the song lyrics forgive me album, what Indonesian moral values are found in the song lyrics forgive me album, and also the moral values are most frequent in song lyrics forgive me album.

In the second step, the researchers is more involved in the representation or display of data that have been collected and analyzed before, because as well all know that qualitative research is more compose narrative text. The display of data is intended to make the data reduction results can be organizes, arranged in a pattern that connected so become easy to understand. This process is done by displaying the data reduction result obtained from the song lyrics "Forgive Me" album. When the data has been collected and displayed, further the researcher comparing and listing the moral values that contained in these song lyrics with 18 Indonesian moral values

In the last step, the researcher makes conclusion and verify through the result on data display. The process of data verification is clear by reading the song lyrics again and also checked the result data. Another data which might change the result when the data process of verification has been done and the result is the same with the data that was obtained before, then researcher could take a conclusion. According to Moloeng (2007), triangulation is a method of cross checking data using other things to search for regularities in the research data. The purpose of triangulation is to increase the credibility and validity of the research. In this study the researcher is using the datatriangulation and theoretical triangulation. The researcher firstly analyzed the data though a theoretical triangulation. In this case, the researcher used two theories of moral values proposed byHornby (2005), and Durkheim (1973). The researcher used these two theories in order to improve the validity of the findings. Therefore, this study concluded the findings deductively based on those two theories. Another way, this researcher is also checked by using data triangulation. The data have been used are some sources such as document, song lyrics note, and similar research about moral values. Though this process, the validity of the findings would be achieved. If the data of each method are the same, then the validity is upheld.

\section{FINDINGS AND DISCUSSION}

As has been stated in chapter one referring to the research question, the main source of data in this research is document. So the data findings in answering the first research question about moral values that reflected in the song lyrics of Forgive Me album by Maher Zain.

Firstly, the researcher analyzed the song lyrics to collect the data by used the document. The researcher read the song lyrics to confirm the data of moral values in the song lyric are matching with the criteria of moral values. And furthermore to answer the second and third research question, the researcher comparing and listing the moral values used the criteria of moral values.

4.1. Research Findings

Answering the first research question concerning about kinds of moral values, so the findings of moral values in this song lyrics were done by the researcher 
though analysis of moral values in the song lyrics of forgive me album by Maher Zain based on the document and criteria of moral value.

After following the procedure of data collection, the researcher found eleventh kinds of Moral values namely (1) religiosity, (2) love and affection, (3) loyalty, (4) sincerity, (5) thankfulness, (6) steadfastness, (7) humbleness, (8) peace loving, (9) brotherhood, (10) respecting others and (11) optimism, in the song lyrics of forgive me album by Maher Zain. Below is the research findings table about moral values found in the Maher Zain's song lyrics in the forgive me album.

1. Religiosity

The first moral value found in this research was religiosity. The researcher found thirteen quotations of lyrics in the title song I Love you so, Mawlaya, My little girl, Assalamu'alayka, Paradise, Radhitu Billahi Rabba, and Guide me all the way that categorized as religiosity and be found in the codes of; $1.1 \mathrm{~A} ; 1.1 \mathrm{~B} ; 1.1 \mathrm{C} ; 1.1 \mathrm{D} ; 1.1 \mathrm{E} ; 1.1 \mathrm{~F} ; 1.1 \mathrm{G} ; 1.1 \mathrm{H} ; 1.1 \mathrm{I} ; 1.1 \mathrm{~J} ; 1.1 \mathrm{~K}$; $1.1 \mathrm{~L} ; 1.1 \mathrm{M}$.

2. Love and Affection

The second moral value found in this research was love and affection. The researcher found five quotations of lyrics in the title song is I love you so, number one for me, mawlaya, my little girl and one big family that categorized as love and affection and be found in the codes of; $1.2 \mathrm{~A} ; 1.2 \mathrm{~B} ; 1.2 \mathrm{C} ; 1.2 \mathrm{D}$; $1.2 \mathrm{E} ; 1.2 \mathrm{~F}$

3. Loyalty

The third moral value found in this research was loyalty. The researcher found five quotations of lyrics in the title song number one for me, radhitu billahi rabba, and so soon that categorized as loyalty and be found in the codes of; 1.3A; 1.3B; 1.3C; 1.3D; 1.3E.

4. Sincerity

The fourths moral value found in this research was sincerity. The researcher found three quotations of lyrics in the title song Number one forme, and Assalamu'alayka that categorized as sincerity and be found in the codes of; 1.4A; 1.4B; 1.4C.

5. Thankfulness

The fifth moral value found in this research was thankfulness. The researcher found three quotations of lyrics in the title song I Love you so, Number one for me, and My little girl that categorize as thankfulness and be found in the codes of; $1.5 \mathrm{~A} ; 1.5 \mathrm{~B} ; 1.5 \mathrm{C}$.

6. Steadfastness

The sixth moral value found in this research was steadfastness. The researcher found two quotations of lyrics in the title song Number one for me and So Soon that categorize as steadfastness and be found in the codes of; $1.6 \mathrm{~A} ; 1.6 \mathrm{~B}$.

7. Humbleness

The seventh moral value found in this research was humbleness. The researcher fund only one quotation of lyrics in the title song Forgive Me that categorize as humbleness and be found in the code of 1.7A.

8. Peace Loving

The eight moral value found in this research was peace loving. The researcher found only one quotation of lyrics in the title song One big family that categorize as peace loving and be found in the code of $1.8 \mathrm{~A}$. 
9. Brotherhood

The ninth moral value found in this research was brotherhood. The researcher found three quotations of lyrics in the title song One big family, and Freedom that categorize as brotherhood and be found in the codes of; 1.9A; 1.9B; $1.9 \mathrm{C}$.

10. Respecting others

The tenth moral value found in this research was respecting others. The researcher found two quotations of lyrics in the title song Assalamu'alayka and So Soon that categorize other and be found in the codes of; 1.10A; 1.10B.

11. Optimism

The eleventh moral value found in this research was optimism. The researcher found three quotations of lyrics in the title song Paradise and I love you so that categorize as optimism and be found in the codes of; 1.11A; 1.11B; $1.11 \mathrm{C}$.

Based on the cathegories, we can conclude that religiosity, love and affection and loyalty are the most moral values that appear in forgive me album. Religiosity has thirteen item, love and affection has six item, loyalty has five item, sincerity has three item, thankfulness also has three item, steadfastness has only two item, humbleness and peace loving has only one item, brotherhood has three item, respecting other has two item and optimism has three item.

4.2. Discussion

The researcher discusses the result of Maher Zain's song lyrics in Forgive Me album. There are some explanations about the Moral Values based on the song. Here are the explanations of the Moral Values found in the song lyrics:

1. Religiosity

One of the religiousity moral values can be found in the song lyrics $\boldsymbol{I}$ Love you so Code: 1.1A. Here the singer told or taught to the listener that he was deeply in intense capacity in praying. In Islam Five time prayers are the obligation of its followers. Praying to God does not only use body but also use heart and soul. Then, all people will get peace to experience their daily life.

Another religiousity moral values can be found in; Song Lyric Mawlaya

Code: 1.1D; Song Lyric My Little Girl Code: 1.1E; Song Lyric Paradise Code: 1.1G; Song Lyric Radhitu Billahi Rabba Code: 1.1I; Song Lyric Guide Me All The Way Code: 1.1L.

2. Love and Affection

One of the love and affection moral values can be found in the song lyric I Love you so Code: 1.2A. In the song lyrics described that the singer always love to his God or Allah. It sounds prettier in the third and fourth line in the stanza above. Only Allah can handle all trouble in his heart and Allah would give points for problems or unrest.

Another love and affection moral values can be found in; Song Lyric Number One for Me Code: 1.2B; Song Lyric Number One for Me Code: 1.2C; Song Lyric Mawlaya Code: 1.2D; Song Lyric My Little Girl Code: 1.2E; Song Lyric One Big Family Code: 1.2F.

3. Loyalty

One of the loyalty moral values can be found in the song lyric Number One for Me Code: 1.3A. The word "You" in the song lyrics refer to "Mother". The singer's loyalty to his mother and make her to be number one. She is the first person who teaches everything to the children from the beginning. She is a 
person who always forgives her children's mistakes. It is prove that the singer really love his mother.

Another loyalty moral values can be found in; Song Lyric Radhitu Billahi Rabba Code: 1.3B; Song Lyric Radhitu Billahi Rabba Code: 1.3C; Song LyricsSo Soon Code: 1.3D; Song Lyric So Soon Code: 1.3E.

4. Sincerity

One of the sincerity values can be found in the song lyric Number One for Me Code: 1.4A. Here the singer shows his sincerity in the part of lyrics above. The song lyrics tell to hearer how the singer loved his mother so much. Some naughtiness had been done when he was a child until grows up now, but his mother always cares. He wants to love his mother like she loves him. Now, the singer feels his mother is someone that important for him.

Another sincerity moral values can be found in; Song Lyric Assalamu, alayka Code: 1.4B; Song Lyric Assalamu’alayka Code: 1.4C.

5. Thankfulness

One of the thankfulness values can be found in the song lyric I Love you so Code: 1.5A. Loyalty is also shows in the part of song lyrics I Love You so. The singer always grateful to Allah and he shows his loyalty with praises. God gives him strength to make him stronger when he is in difficult time. God is the only one who inspires his life.

Another thankfulness moral values can be found in; Song Lyric Number One for Me Code: 1.5B; Song Lyric My Little Girl Code: 1.5C.

6. Steadfastness

One of the steadfastness values can be found in the song lyricNumber One for Me Code; 1.6A. The song lyrics tell about when the singer was a child. At that time he was so naughty. The singer always makes his mother cried and felt pain. Nevertheless, His mother always cares and loves him until he grows up. To make him to raise him growing adult is not easy for her.

Another steadfastness moral values can be found in; Song Lyrics So Soon Code; 1.6B.The song lyrics tell his steadfastness when his father or mother left him alone. The singer tries to deal what he gets and learns about it. He tried to stop his tears and be strong. He had to face everything, even though it was very difficult for him.

7. Humbleness

One of the humbleness values can be found in the song lyric Forgive Me Code: 1.7A. Forgive Me song lyrics show how God is having a modest characteristic. The God is the Most Forgiving to the person that wants return to the Him right way. He is always around for the person who needs Him.

8. Peace Loving

One of the peace loving values can be found in the song lyricOne Big Family Code: 1.8A. In the part of stanza above, it talks about there is no differences between us. Peace loving is shown in the first line, the singer alert the people that be family. Become a family also gives interdependent, care, and protection.

9. Brotherhood

One of the brotherhood values can be found in the song lyric One Big Family Code: 1.9A. The lyrics tell that all of the people belong to one family. Although the people did not know one another and they have not met before. The singer also tells about even so the people are in different place, culture, skin, genre, they are belongs to one family. 
Another brotherhood moral values can be found in; Song Lyric Freedom Code: 1.9B; Song Lyric Freedom Code: 1.9C.

10. Respecting others

One of the respecting others values can be found in the song lyric Assalamu'alayka Code: 1.10A. The song lyrics tell about Respect to Muhammad as a Prophet. The singer gives praises to his prophet. Assalamu'alayka song disclose how the singer love and longing to Prophet Muhammad.

Another respecting others moral values can be found insong lyric So

SoonCode: 1.10B. This lyrics deal with the idea of respecting to his parents passed away. As a child he always prays to his mother or father. He does it every day and night when he made his prayer.

11. Optimism

One of the optimism values can be found in the song lyric Paradise Code: 1.11A. The song lyrics tell about optimism about he and his wife will be together in paradise. Paradise is place where the pieties people will stay enduringly. Every day and night he and his wife always pray to God so that they will be in paradise one day.

On the album forgive me, there were three moral values that most appear in the songs forgive me albums. In this album, Maher Zain wanted to give something different. The concept of the album was not his full about Islam, but still contains elements of Islam. Because Islam was a part of our daily life.

The moral of religion were most numerous in the songs in the album "forgive me, which is thirteen moral religiosity on some songs. the title "I love you so", in the first lyrics, Maher Zain using the phrase God, for appeals to the gods, the message delivered by Maher Zain other than in the form of prayers, is also invitation to goodness, that is also where there is a message of monotheism. In the lyric "I pray to god ', Maher Zain no longer use the word' god 'but ' Allah'. Here Maher Zain tells us that God is merely Allah.

Then there were also six moral values of love and affectionand also three moral values of loyalty which was describe about our mothers, Islam teaches about how we treat the mother, how we love mother, or about friendship, harmony, like the songs on big family, my little girl. In the song Maher Zain convey his feeling for his daughter Aya Zain.

\section{CONCLUSIONS AND SUGGESTIONS}

5.1. Conclusions

The following conclusions are presented based on the research findings to answer each research question in this study:

1) Moral Values

Based on the research conducted, it was concluded that there are eleven types of moral values seen on song lyrics of Forgive Me album by Maher Zain, they are: religious, love and affection, loyalty, sincerity, thankfulness, steadfastness, humbleness, peace loving, brotherhood, respecting others, and optimism.

2) Indonesian Moral Values are found in the Song lyrics album by Maher Zain. They are three types of moral values that similar with the 18 Indonesian moral values such as religiosity, peace loving and communicative.

3) The moral values that most frequent in the song lyrics are religiosity, love and affection and loyalty. 


\subsection{Suggestion}

Finally based on the findings and the significances of this study, the researcher wants to give some suggestions for:

1) English Department Students

The findings of this study are also can be used as a reference for English Department students who study moral value. Especially in understanding the theory about illocutionary acts and their illocutionary forces in a speech.

2) The Teachers

The teacher also suggested using song lyrics while teaching moral values to make it easier and more interested.

3) The Next Researchers

This study also can give a contribution for the next researchers who are interested in investigating similar field of study. They can use the findings as reference to understand the theory of moral values. And the researcher suggested them to have more literatures related to this study in order to make the theories more complete. Besides that, they also can use these findings as comparison and direction for their future research particularly on the way of analyzing moral values not only in the song lyrics. In addition, the researcher is also suggested finding the other subject to be analyzed. For example: poetry or novel.

\section{REFERENCES}

Durkheim, Emil. (1973) Moral Education: A study in the Theory and Application of the Sociology of Education. Ondon: Mecmilan Publishing Co., Inc

Emzir. (2010). Methodology Penelitian Kualitatif; Analysis Data. Jakarta: Raja Grafindo

Landau, Likewise. Sydney. (2002). Webster's Student Dictionary of English Language USA: Trident Press International.

Lexy J, Moloeng. (2007). Metode Penelitian Kualitatif. Bandung: Remaja Rosdakarya.

Little, Graham. (1970). Approach to Literature. Sydney: Science Press.

Niken, Kartika Sari Arista. (2014) The Poetic and Moral Values Analysis Seen on Song Lyrics of Forgive Me Album by Maher Zain. (Thesis S1) State Islamic Institute (STAIN) Salatiga Publishing. http://perpus.iainsalatiga.ac.id/docfiles/fulltext/62f89513bbf285d6.pdf

Paramita, Orissa. (2015). An Analysis of Moral Values in 'Wreck it Ralph' Movie Directed by Rich Movie. Thesis S1 Unpublished. Samarinda: Mulawarman University.

Pusat Pendidikan DIKNAS. (2010). Tujuandan Pentingnya 18 Nilai Pendidikan Karakter di Indonesia. Retrived from http://tipspendidikanku.blogspot.com/2014/07/pengertian-tujuan-dan-18nilai.html

Rae, Scott B. (2002). Moral Choice: An Introduction to Ethnics. Michigan: Zondervan Publishing House. 
Susanti, Dani Atik. (2012) An Analysis of Moral Values Taken from Edensor Novel by Andrea Hirata. (Thesis S1) State Islamic Institute (STAIN) Salatiga Publishing. http://perpus.iainsalatiga.ac.id/docfiles/fulltext/d12ae160f775571b.pdfSo urce:http://belajarpsikologi.com/pengertianpendidikankarakter/\#ixzz37xu $\underline{\mathrm{eB} 25 \mathrm{p}}$

Walker, Margaret Urban. (1998) Moral Understanding: A Feminist Study in Ethnics. New York. Routledge. 